\title{
AGORA: REFLECTIONS ON ZIVOTOFSKY V. KERRY HISTORICAL GLOSS, THE RECOGNITION POWER, AND JUDICIAL REVIEW
}

\author{
Curtis A. Bradley*
}

The U.S. executive branch has long declined to recognize any country's sovereignty over Jerusalem, insisting that the matter be worked out through negotiations between Israel and the Palestinians. The U.S. Congress, by contrast, has tended to support Israeli sovereignty over the city. In 2002, Congress enacted the Foreign Relations Authorization Act for Fiscal Year 2003, Section 214(d) of which provides that, "[f]or purposes of the registration of birth, certification of nationality, or issuance of a passport of a United States citizen born in the city of Jerusalem, the Secretary [of State] shall, upon the request of the citizen or the citizen's legal guardian, record the place of birth as Israel."1 Both the Bush Administration and the Obama Administration declined to comply with this statutory directive. In Zivotofsky v. Kerry (Zivotofsky II), the Supreme Court sided with the executive branch, holding that Section 214(d) unconstitutionally interferes with the exclusive authority of the President to recognize foreign sovereigns. ${ }^{2}$

The focus of this essay is on the Court's methodology rather than its conclusion. In particular, the focus is on the Court's reliance on the historic practices of Congress and the executive branch in support of the Court's finding of an exclusive presidential recognition power. Reliance on such practice—also known as "historical gloss"-is common in constitutional interpretation relating to the separation of powers. For a variety of reasons, however, there are unlikely to be many instances in which historical practice will clearly establish an exclusive presidential power. In Zivotofsky II, the relevant practice provided clear support only for a power of recognition and was ambiguous about whether this power was concurrent or exclusive. The Court's assessment of the practice, therefore, appears to have been affected by other considerations, such as the Court's perception about the consequences of adopting a particular interpretation. This is not necessarily an indictment, given that a similar dynamic often characterizes other aspects of constitutional interpretation, including textual analysis. It is probably fair to say, however, that whereas in some cases historical practice shapes perceptions about other interpretive materials, in Zivotofsky II the principal direction of influence was the other way around. The decision also highlights tensions between a custom-based approach to the separation of powers and the institution of judicial review, tensions that are potentially relevant both to the proper scope of justiciability doctrines as well as to the way in which judicial decisions are best formulated.

* William Van Alstyne Professor, Duke Law School. For their helpful comments and suggestions, he would like to thank Kathy Bradley, Jean Galbraith, Jack Goldsmith, Neil Siegel, and Carlos Vázquez:

Originally published online 20 July 2015.

${ }^{1}$ Foreign Relations Authorization Act, Fiscal Year 2003, Pub. L. No. 107-228, 116 Stat. 1350, 1366 (2002).

2 Zivotofsky ex rel. Zivotofsky v. Kerry, 135 S.Ct. 2076 (2015) [hereinafter Zivotofsky II]. 


\section{Historical Gloss and the Separation of Powers}

Historical practice often plays a significant role in assessments of the Constitution's distribution of authority among the three federal branches of government, especially in the area of foreign affairs. ${ }^{3}$ Judicial precedent tends to be sparse on questions relating to the separation of powers, and historical practice can provide an alternative form of precedent. Moreover, crediting such practice can be a way of respecting the constitutional judgments of non-judicial actors. There also can be consequentialist justifications for deferring to practicefor example, it can be a way of protecting expectation interests that may have developed in light of the practice and avoiding unanticipated consequences that may stem from deviating from it.

Reliance on historical practice is especially common in assessments of presidential power. Part of the reason is that the text of the Constitution provides relatively little guidance on this topic. Unlike the laundry list of congressional powers in Article I, Section 8 of the Constitution and other constitutional provisions, Article II mentions only a few presidential powers, and a number of the ones it mentions (such as the treaty power) are shared with the Senate. By necessity, claims about presidential power often rest on purported implications of the few specific textual grants of authority, inferences from the more general constitutional structure, or the controversial idea of unspecified "residual" powers conveyed through the first sentence of Article II ("The executive Power shall be vested in a President of the United States of America."). ${ }^{4}$ These materials, however, will often be unclear and contested, and historical practice can help support or undermine particular interpretations.

The now canonical framework for assessing presidential power is the one set forth by Justice Jackson in his concurrence in the Youngstown steel seizure case. ${ }^{5}$ Under this framework, which Jackson acknowledged to be "a somewhat over-simplified grouping," ${ }^{6}$ presidential power is assessed based on three categories. In the first category, in which the President acts with the express or implied authorization of Congress, his power is "at its maximum." In the second category, in which there is neither a congressional grant nor denial of authority, "there is a zone of twilight in which [the President] and Congress may have concurrent authority, or in which its distribution is uncertain." "In the third category, in which the President takes actions contrary to the express or implied will of Congress, "his power is at its lowest ebb."9 Justice Jackson recognized that presidential actions would still be lawful in the third category to the extent that the President was exercising authority assigned exclusively to him by the Constitution, although Justice Jackson cautioned that a claim to such exclusive authority "must be scrutinized with caution, for what is at stake is the equilibrium established by our constitutional system."10

\footnotetext{
3 See generally Curtis A. Bradley \& Trevor W. Morrison, Historical Gloss and the Separation of Powers, 126 Harv. L. REv. 411 (2012).

${ }^{4}$ The Supreme Court noted in Zivotofsky II that, because it had concluded that the President's recognition power was supported by specific constitutional text, it "need not consider whether or to what extent the Vesting Clause ... provides further support for the President's action here." Zivotofsky II, 135 S.Ct. at 2086. Justice Thomas was the only member of the Court to endorse a reading of the Vesting Clause that would encompass residual powers, see $\underline{i d}$. at 2097-2098 (Thomas, J., concurring), and Justice Scalia's dissent (joined by Chief Justice Roberts and Justice Alito) seemed critical of the idea. See $\underline{i d}$. at 2126 (Scalia, J., dissenting) (referring to Justice Thomas's “assertion of broad, unenumerated 'residual powers' of the President”). For differing academic accounts of the Vesting Clause, compare Saikrishna B. Prakash \& Michael D. Ramsey, The Executive Over Foreign Affairs, 111 Yale L.J. 231 (2001), with Curtis A. Bradley \& Martin S. Flaherty, Executive Power Essentialism and Foreign Affairs, 102 Mich. L. Rev. 545 (2004).

5 See Youngstown Sheet \& Tube Co. v. Sawyer, 343 U.S. 579, 635-38 (Jackson, J., concurring).

${ }^{6} \underline{I d}$. at 635.

${ }^{7} \underline{I d}$.

${ }^{8} \underline{I d}$. at 637.

${ }^{9} \underline{I d}$.

${ }^{10} \underline{I d}$. at 638 .
} 
The invocation of historical practice in discerning the separation of powers is often identified with a different concurrence in Youngstown - the one by Justice Frankfurter. Justice Frankfurter observed that "[i]t is an inadmissibly narrow conception of American constitutional law to confine it to the words of the Constitution and to disregard the gloss which life has written upon them."11 He also contended that

a systematic, unbroken, executive practice, long pursued to the knowledge of the Congress and never before questioned, engaged in by Presidents who have also sworn to uphold the Constitution, making as it were such exercise of power part of the structure of our government, may be treated as a gloss on "executive Power" vested in the President by $\int 1$ of Art. II.12

Not all articulations of the standards for gloss are as demanding as Frankfurter's, and in crediting practice the Supreme Court has not typically required that it be "unbroken" or "never before questioned." In addition, while Frankfurter referred specifically to the first clause of Article II of the Constitution, gloss has been invoked to help interpret a variety of other constitutional clauses, relating both to executive and legislative authority, as well as to interpret broader structural principles.

Whatever the appropriate text, such "historical gloss" is potentially relevant to all three of Justice Jackson's categories. It is most obviously relevant to his second, "zone of twilight" category, where the distribution of authority is especially uncertain. But it is also potentially relevant to the first and third categories. Those categories refer to the implied as well as express will of Congress, and, as the Supreme Court has recognized, historical practice can help inform what Congress has implicitly authorized or disapproved. ${ }^{13}$ Of most relevance to Zivotofsky II, practice can also, at least in theory, help an interpreter identify when Congress has exceeded its authority or intruded upon the exclusive authority of the President-issues of particular concern under Justice Jackson's third, "lowest ebb" category.

Although the Supreme Court has endorsed the relevance of historical gloss to the separation of powers in a number of decisions, its decision last Term in NLRB v. Noel Canning provided an especially strong endorsement of this approach to constitutional interpretation. ${ }^{14}$ In concluding that the President's power to make recess appointments applied even during "intra-session" recesses of the Senate, and even when the vacancy that was being filled pre-dated the recess, the Court in Noel Canning accorded what it described as "significant weight" to historical practice relating to the recess appointments power. ${ }^{15}$ The Court made clear that " $[\mathrm{t}]$ he longstanding 'practice of the government,' ... can inform this Court's determination of 'what the law is' in a separation-ofpowers case."16

${ }^{11} \underline{I d}$ at 610 (Frankfurter, J., concurring).

${ }^{12} \underline{I d}$. at $610-11$.

13 See, e.g., Medellin v. Texas, 552 U.S. 491, 531-32 (2008); Hamdi v. Rumsfeld, 542 U.S. 507, 519 (2004) (plurality opinion); Dames \& Moore v. Regan, 453 U.S. 654, 686 (1981).

${ }^{14}$ NLRB v. Canning, 134 S. Ct. 2550 (2014).

$15 \underline{I d}$. at 2559 (citations omitted).

${ }^{16} \underline{I d}$. at 2559-60. For analysis of this decision, see Curtis A. Bradley \& Neil S. Siegel, After Recess: Historical Practice, Textual Ambiguity, and Constitutional Adverse Possession, 2014 SUP. CT. REv. 1. 


\section{Historical Gloss in Zivotofsky II}

In Zivotofsky II, the Court referred to Noel Canning and noted that, "[h]aving examined the Constitution's text and this Court's precedent, it is appropriate to turn to accepted understandings and practice." 17 While acknowledging that the practice relating to recognition was "not all on one side," the Court thought that, "on balance it provides strong support for the conclusion that the recognition power is the President's alone."18

Whether the practice cited by the Court provided "strong support" is questionable. There is little dispute that the practice supported a presidential power to make determinations concerning the recognition of foreign sovereigns and their territory. It is much less clear, however, that the practice established that this recognition power was exclusive, such that it could not be regulated by Congress. ${ }^{19}$ During the nineteenth century, there was uncertainty and dispute about whether and to what extent Congress could regulate issues relating to recognition. Congress sometimes declined to take contemplated action concerning recognition in the face of executive branch opposition (for example, relating to South American countries in the early nineteenth century), ${ }^{20}$ but it is not clear whether this restraint was the result of policy concerns or constitutional doubts (and different members of Congress may of course have had different motivations). Conversely, presidents sometimes accommodated congressional preferences about recognition (for example, President Jackson's accommodation of Congress's desire to recognize Texas in the 1830s, and President Lincoln's solicitation of Congress's views regarding the recognition of Haiti and Liberia in 1861), ${ }^{21}$ but it is not clear whether they did so for political or constitutional reasons.

To be sure, the practice since the early twentieth century has been primarily one of executive branch management of recognition issues, without much objection from Congress. As the Court noted in Zivotofsky II, "[o]ver the last 100 years, there has been scarcely any debate over the President's power to recognize foreign states." 22 By itself, however, this modern history merely supports a unilateral presidential recognition power, not necessarily an exclusive recognition power. While Congress's general lack of regulation of recognition in this period might stem from a congressional acceptance of exclusive presidential authority, it might also stem simply from the fact that Congress has not generally disagreed with the President's actions.

The ambiguous nature of the practice does not necessarily mean that the Court reached the wrong conclusion. Customary practices are never self-defining; they always must be interpreted and categorized. That is, applications of constitutional custom, like applications of customary international law, involve an element of law-creation, akin to the judicial development of the common law. ${ }^{23}$ Determinations of constitutional custom, moreover, are inevitably affected by other "modalities" of constitutional interpretation, including the interpreter's views about the constitutional structure and about the consequences of a particular interpretation. This was evident in Zivotofsky II: the Court emphasized structural inferences and what it referred to as "functional

17 Zivotofsky II, 135 S.Ct. at 2091.

${ }^{18} \underline{I d}$.

19 See Robert J. Reinstein, Is the President's Recognition Power Exclusive?, 86 TeMPLE L. ReV. 1 (2013). Reinstein concludes that historical practice "provides little support for any claim of an exclusive recognition power," $\underline{i d}$. at 8 , although he also acknowledges that "[a] possible interpretation of the post-ratification history is that Congress cannot overturn an executive recognition decision but can take other actions that determine the policies by which the recognition is effectuated," $\underline{i d}$. at $56 \mathrm{n} .370$.

20 See Zivotofsky II, 135 S.Ct. at 2092.

21 See $\underline{i d}$. at $2092-2093$.

$22 \underline{I d}$. at 2094 .

${ }^{23}$ Cf. Curtis A. Bradley, Customary International Law Adjudication as Common Law Adjudication, in CusTOM's FutURE: INTERNATIONAL LAW IN A CHANGING WORLD (Curtis A. Bradley ed., forthcoming) (describing how the interpretation of customary international law in international adjudication often resembles common law decisionmaking). 
considerations" in support of an exclusive presidential recognition power, and it interpreted congressional inaction relating to recognition as reflecting an acceptance of these inferences and considerations. ${ }^{24}$ The interdependence of interpretive materials in constitutional interpretation is not unique to historical gloss. 25

It seems fair to say, however, that whereas in some cases (such as Noel Canning) historical practice shapes perceptions about other interpretive materials, in Zivotofsky II it was largely the other way around. If history were the only relevant consideration, the Court easily could have concluded that the presidential recognition power was concurrent rather than exclusive. Nevertheless, it would be going too far to conclude from this that the Court's reference to historical practice in Zivotofsky II was mere window dressing. The post-nineteenth century practice concerning recognition was dominated by the executive branch, and this fact helped to reinforce the Court's finding of exclusivity, even though it was not by itself sufficient to sustain that conclusion. History mattered, but it mattered less than it did in Noel Canning, and it was not the only thing that mattered.

The ambiguous nature of the historical practice in Zivotofsky II also reveals a more general issue: although historical practice is in theory relevant to Jackson's third category, it is likely to be difficult to find clear historical evidence supporting an exclusive presidential power. ${ }^{26}$ Among other things, there are not many instances like the one in Zivotofsky II in which presidents directly defy clear statutory directives. Instead, the political branches generally find a way to resolve their disputes without a constitutional impasse. Before the enactment of Section 214(d), this had been true about recognition. As the Court observed in Zivotofsky II, "[u]ntil today, the political branches have resolved their disputes over questions of recognition." 27 The closest analogue to Section 214(d) was Congress's directive in the 1990s that the executive branch allow U.S. citizens born in Taiwan to have their place of birth recorded as "Taiwan." 28 But that measure was distinguishable from Section 214(d) because it did not take a position on whether Taiwan was part of, or separate from, mainland China, whereas Section 214(d) specifically linked Jerusalem to Israel. ${ }^{29}$

Despite its limitations, historical gloss seems more established than ever as part of the Supreme Court's approach to constitutional interpretation concerning the separation of powers. Notably, even the Justices who did not join the majority opinion in Zivotofsky II accepted the relevance of post-Founding historical practice. Justice Thomas, in arguing that the President's recognition power stemmed from the Article II Vesting Clause, invoked not only originalist materials but also the "President's longstanding practice of exercising unenumerated foreign affairs powers," as well as "[t]he history of the President's passport regulation in this country." 30 Chief Justice Roberts also seemed to accept some role for historical practice, although he insisted that it did not show that Congress had accepted an exclusive presidential recognition power. ${ }^{31}$ Justice Scalia, in contesting the Court's conclusion that Section 214(d) unconstitutionally interfered with the President's recognition power,

24 See Zivotofsky II, 135 S.Ct. at 2079, 2086.

25 See generally Curtis A. Bradley \& Neil S. Siegel, Constructed Constraint and the Constitutional Text, 64 DuKE L.J. 1213 (2015); Richard H. Fallon, Jr., A Constructivist Coherence Theory of Constitutional Interpretation, 100 HARV. L. REV. 1189 (1987).

${ }^{26}$ Cf. Curtis A. Bradley, Treaty Termination and Historical Gloss, 92 Tex. L. Rev. 773, 825 (2014) (finding that, while modern historical practice supported a unilateral presidential power of treaty termination, "there is no significant historical practice to support the Executive Branch's claim" that such a power is exclusive).

${ }^{27}$ Zivotofsky II, 135 S.Ct. at 2088.

28 See Foreign Relations Authorization Act, Fiscal Years 1994 and 1995, Pub. L. No. 103-236, § 132, 108 Stat. 395.

29 See Zivotofsky II, 135 S.Ct. at 2107 (Thomas, J., concurring) ("Because the President otherwise treats Taiwan as a geographical area within the People's Republic of China, listing Taiwan as the place of birth did not directly conflict with the President's prevailing practices.").

${ }^{30} \underline{I d}$. at 2097, 2102 (Thomas, J., concurring).

31 See $\underline{i d}$. at 2114 (Roberts, C.J., dissenting). Chief Justice Roberts also suggested that congressional acquiescence should not be credited in discerning exclusive presidential authority. See id. But $c f$. Myers v. United States, 272 U.S. 52, 163 (1926) (relying in part on congressional acquiescence in support of an exclusive presidential power of removal of executive officers). 
argued that "Congress has legislated without regard to recognition for a long time and in a range of settings." 32 In addition, in contesting Justice Thomas's claim that Congress lacked affirmative authority to regulate passports, Justice Scalia emphasized that, since the Civil War, "Congress has made laws about eligibility to receive passports, the duration for which passports remain valid, and even the type of paper used to manufacture passports." 33

\section{Judicial Review and Historical Gloss}

The Supreme Court is not a mere neutral reporter on the customary practices of the political branches. Its decisions also shape those practices. In Zivotofsky II, by holding that the President has an exclusive recognition power, the Supreme Court has affected how future practices between the political branches will develop.

This dynamic serves as a reminder of an inherent tension between a custom-based approach to law and centralized judicial review. One of the potential virtues of custom is that it can evolve in response to changing conditions. This is true of customary practice relating to the separation of powers, in that this practice can (at least under certain conditions) evolve based on the political branches' own assessments of what works best over time. Judicial review, however, has the potential to freeze in place a particular arrangement and thereby prevent further evolution. In part because of another custom-judicial supremacy-institutional actors in the United States are likely to coordinate around Supreme Court determinations. ${ }^{34}$

A freezing of customary evolution is not necessarily problematic. Sometimes the benefits of a clear judicial resolution will outweigh the benefits of continuing flexibility. The Court in Zivotofsky II suggested that it thought this was the case with respect to the exclusivity of the recognition power. "A clear rule that the formal power to recognize a foreign government subsists in the President," the Court reasoned, "serves a necessary purpose in diplomatic relations." 35 The Court observed, for example, that other countries needed clear notice of whether they would receive the benefits of recognition by the United States, and that having a clear understanding of the President's exclusive authority with respect to this issue would benefit the United States in international negotiations over matters relating to recognition.

With respect to determinations of presidential power, however, a judicial intervention has the potential to entrench expansions of presidential authority that have developed over time. Commentators concerned about the growth of presidential power often suggest greater judicial review as a corrective. But if judicial review simply results in a confirmation of executive authority, the President's position may be stronger than if the courts had abstained. This is a plausible understanding of what happened in the Zivotofsky II litigation. If the Supreme Court had declined to decide the constitutional question, based on lack of standing or the political question doctrine, Congress would have been able to continue making a credible claim of authority to enact statutory directives like the one in Section 214(d). Zivotofsky II, however, substantially reduces Congress's ability to make such a claim. The decision, moreover, is likely to serve as a useful precedent for the executive branch both in its internal reasoning and in other disputes with Congress. ${ }^{36}$

More generally, Zivotofsky II suggests that the Supreme Court's approach to justiciability cannot be entirely separated from its approach to the merits. In particular, if the Court adopts a formalist approach to justiciability,

32 Zivotofsky II, 135 S.Ct. at 2122 (Scalia, J., dissenting).

${ }^{33} \underline{I d}$. at 2125 (Scalia, J., dissenting).

${ }^{34}$ For a comparable issue concerning international adjudication of customary international law, see Suzanne Katzenstein, International Adjudication and Custom Breaking by Domestic Courts, 62 DukE L.J. 671, 673 (2012) ("[F]or a specific class of cases—those involving custom breaking - international adjudication risks impeding the traditional process by which [customary international law] evolves.")

35 Zivotofsky II, 135 S.Ct. at 2088.

36 See Jack Goldsmith, Why Zivotofsky is a Significant Victory for the Executive Branch, LAWFARE (June 8, 2015, 3:44 PM). 
and thereby suppresses prudential considerations at that stage, it is quite possible that these considerations will reemerge at the merits stage. ${ }^{37}$ Thus, in the first Zivotofsky II decision, the Court adopted a very formalist approach to the political question doctrine, declining even to mention the prudential factors outlined in Baker $v$. Carr (such as "an unusual need for unquestioning adherence to a political decision already made; or the potentiality of embarrassment from multifarious pronouncements by various departments on one question"). Prudential concerns became a significant part of the analysis, however, when the Court addressed the merits in Zivotofsky II. As a result, a prudential approach to non-justiciability should not necessarily be viewed as inherently favoring the growth of executive authority.

That said, the tension between judicial review and a custom-based approach to law can be reduced by judicial approaches other than non-justiciability. In particular, the Supreme Court can seek to minimize the entrenchment effect of its decisions by engaging in what Cass Sunstein has labeled "judicial minimalism." 38 Such an approach would involve, among other things, framing a decision narrowly in terms that fit closely to the particular facts of the dispute, thereby preserving maximum space for customary evolution on potentially related issues. The Court in Zivotofsky II appears to have attempted to do precisely that. It expressly resolved only "the power to recognize or decline to recognize a foreign state and its territorial bounds," and it made clear that it was finding historic congressional acquiescence in exclusive presidential power only "in the narrow context of recognition." " The Court also emphasized that "[t]he Executive is not free from the ordinary controls and checks of Congress merely because foreign affairs are at issue," and that "Congress has an important role in other aspects of foreign policy, and the President may be bound by any number of laws Congress enacts." 40 In addition, the Court declined to rest its decision on the broad presidential power dicta in United States v. CurtissWright Export Corporation, ${ }^{41}$ noting that "[a] formulation broader than the rule that the President alone determines what nations to formally recognize as legitimate ... presents different issues and is unnecessary to the resolution of this case." 42

Of course, it is possible that the Court could have been even more minimalist in its decision. In particular, it could have concluded, as Zivotofsky argued, that Section 214(d) did not interfere with the President's recognition policy concerning Jerusalem, and thereby avoided deciding whether the President had an exclusive recognition power. Particularly given the sensitive Middle East backdrop of the case, however, it is not surprising that the Court gave some deference to the executive branch's contrary assessment of Section 214(d)'s effect. 43

37 See Curtis A. Bradley, Zivotofsky and Pragmatic Foreign Relations Law, ScotusBlog (June 9, 2015, 9:16 AM).

38 See, e.g., Cass R. Sunstein, Burkean Minimalism, 105 Mich. L. REV. 353 (2006).

39 Zivotofsky II, 135 S.Ct. at 2094.

${ }^{40} \underline{I d}$. at 2088.

${ }^{41}$ See id. at 2089.

${ }^{42} \underline{I d}$. The Court's disavowal of the Curtiss-Wright dicta and its endorsement of congressional authority in foreign affairs caused some commentators to see the decision as potentially serving to limit rather than expand presidential authority. See, e.g., Michael Dorf, Zivotofsky May be Remembered as Limiting Exclusive Presidential Power, DorF ON LAw (June 8, 2015, 12:52 PM); Michael J. Glennon, Recognizable Power: The Supreme Court Deals a Blow to Executive Authority, FOREIGN AfFAirs SNAPSHOT (June 23, 2015).

43 The Court's deference to the executive branch concerning the likely affect of enforcing Section 214(d) on U.S. foreign relations was subtle. In concluding that the statute had the effect of contradicting the executive branch's recognition policy concerning Jerusalem, the Court quoted the D.C. Circuit's finding to that effect. See Zivotofsky II, 135 S.Ct. at 2080. The D.C. Circuit's finding in turn reflected deference to the executive branch. See Zivotofsky v. Secretary of State, 725 F.3d 197, 217 (D.C. Cir. 2013) ("We find the Secretary's detailed explanation of the conflict between section 214(d) and Executive recognition policy compelling, especially given 'our customary policy to accord deference to the President in matters of foreign affairs."') (citation omitted). During the oral argument in Zivotofsky II, Justice Kennedy, who ended up writing the majority opinion, indicated that he thought deference was appropriate. See Transcript of Argument, Zivotofsky v. Kerry, No. 13-628, at 18-19 (Nov. 3, 2014). 


\section{Conclusion}

Zivotofsky II provides additional confirmation of the relevance of the "historical gloss" approach to constitutional interpretation, both in the general area of separation of powers and in the more specific area of foreign relations law. At the same time, the decision highlights some of the limitations of this approach, especially for resolving direct conflicts between Congress and the executive branch, as well as certain tensions between a practice-based approach to constitutional interpretation and the institution of judicial review. To its credit, the Court in Zivotofsky II was sensitive to these limitations and tensions. 